in the United Kingdom for the Human Relations Area Files from New Haven, Connecticut. In the intervening period inquiries should be addressed (from September 1970) to Professor H. W. Turner, Candler School of Theology, Emory University, Atlanta, Ga. 30322, U.S.A., or to Professor R. N. Smart at Lancaster.

\title{
The Herskovits Award for 1969
}

Dr. Paul and Dr. Laura Bohannan were awarded the 1969 Herskovits Award of the African Studies Association (U.S.A.) for their book, Tiv Economy. They are the authors of the International African Institute's Ethnographic Survey section on The Tiv of Central Nigeria, which was reprinted in 1969 with a supplementary bibliography. Dr. Paul Bohannan's study of Justice and Judgment among the Tiv (1957), also published by the Institute, was reprinted in 1968 with a new Preface.

\section{The Co-operative African Microform Project (CAMP)}

CAMP, which is administered by the Center for Research Libraries in Chicago and sponsored by the Archives-Libraries Committee of the African Studies Association, has received a second grant from the U.S. Department of Health, Education, and Welfare, enabling it to buy or film an extensive range of new titles so that by the end of the present fiscal year there should be almost 1,000 titles available. Recent additions include the correspondence and memoranda files of the South African Institute of Race Relations, various newspapers, several hundred out of print books on former French West Africa, a number of Italian books on the Horn, a group of British, American, and continental European dissertations on African topics, a set of Tanganyika District Books, and such major journals as Nigeria Magazine, Gold Coast Review, and Black Orphews.

A number of member libraries have deposited surplus films and negatives in exchange for positives in CAMP; other libraries and individuals are invited to do the same to increase the pool of Africanist materials.

A new prospectus describing the work of CAMP may be obtained from Robert Gordon Collier, Assistant Director of the Center for Research Libraries, 5721 Cottage Grove, Chicago, Ill., 60637. Copies of the Center's Handbook and of the various CAMP accessions lists are also available on request by prospective members.

\section{'Transafrican Journal of History'}

THE first issue of the Transafrican Journal of History, edited by J. A. Kieran (University College, Nairobi) and A. D. Roberts (University of Zambia) will appear in September r970. It will be issued twice a year and will mainly be concerned with the history of eastern and central Africa since about 1800 , though the editors will welcome articles of general interest to African historians on earlier history, and on the history of other parts of the world. The annual subscription (Shs. 20 in East Africa and f2. I 2 s. or $\$ 6$ elsewhere) should be sent to the publishers, East African Publishing House, P.O. Box 30571, Nairobi, Kenya. Articles (which should not normally be more than 7,000 words in length) and books for review should be sent to the editors c/o Dept of History, University College, P.O. Box 30197 , Nairobi, Kenya.

\section{'Studies in African Linguistics'}

The Department of Linguistics and the African Studies Center, University of California, Los Angeles, announces the publication of this new journal of theoretical linguistics. The contents of the first issue (vol. I, no. r) are: 